\title{
PERSEPSIES OOR DIE SINODEBESLUITE EN AARD VAN DIE PSALMS BINNE DIE GKSA
}

\section{Author:}

W. D. Basson ${ }^{1}$

D. Kruger ${ }^{1}$

\section{Affiliation:}

${ }^{1}$ Skool vir Musiek, NoordwesUniversiteit (MASARA), RSA

\section{Correspondence to:}

Diederick Basson

\section{Postal Address:}

Skool vir Musiek, NoordwesUniversiteit, Privaatsak X6001, Potchefstroom, 2520

Email:

bassonwd@gmail.com

\section{Correspondence to:}

Daleen Kruger

\section{Postal Address:}

Skool vir Musiek, NoordwesUniversiteit, Privaatsak X6001, Potchefstroom, 2520

\section{Email:}

daleen.kruger@nwu.ac.za

Dates:

15 Dec. 2016

\section{How to cite this article:} Basson, W.D. \& Kruger, D., 2016. "Persepsies oor die sinodebesluite en aard van die psalms binne die GKSA". KOERS - Bulletin for Christian Scholarship, 81(3). Available at: https://doi.org/10.19108/ KOERS.81.3.2261

\section{Copyright:}

(c) 2016. The Author(s).

Published under the Creative Commons Attribution License.
Perceptions regarding synod decisions and the nature of psalms in the RCSA. Since its inception in 1859, the Reformed Church in South Africa has been singing only psalms, scriptural hymns and Biblical songs. Currently, there are two official versifications of the psalms in use within the Reformed Church, namely the so-called Totius versification of 1936 and the 2001 rhymed version of psalm texts, mainly by T.T. Cloete. A study of members' perceptions of synod decisions and the nature of the psalms in the Reformed Church shows that the psalms are not fully utilised. Synods decide what type of songs, type of songs, including psalms, are approved, are approved for use. Members believe that many psalms are no longer suitable for the 21st-century churchgoer, that synod decisions appear to be out of touch with members' musical needs and that synods oppose musical innovation.

The purpose of this article is to give an overview of ministers, organists/music leaders and parishioners' perceptions regarding the nature and use of psalms during worship in the Reformed Church of South Africa as well as synod decisions pertaining to the psalms.

KEY WORDS: Reformed Churches of South Africa, synod decisions, psalms, psalm text, psalm melody

Die Gereformeerde Kerke in Suid-Afrika sing vanaf die kerk se ontstaan in 1859 slegs psalms, Skrifberymings en Skrifgetroue liedere. Tans is daar twee amptelike psalmberymings in gebruik binne die Gereformeerde Kerk, naamlik die sogenaamde Totius-beryming van 1936, asook die 2001-omdigting met psalmtekste deur hoofsaaklik T.T. Cloete. 'n Studie van lidmate se persepsies oor sinodebesluite en die aard van die psalms binne die Gereformeerde Kerk toon aan dat die psalms nie optimaal benut word nie. Sinodes besluit watter tipe liedere, insluitend psalms, vir gebruik goedgekeur word. Lidmate glo dat talle psalms nie meer geskik is vir die 21ste-eeuse lidmaat nie, dat sinodebesluite uit voeling is met lidmate se musikale behoeftes en dat sinodes musikale vernuwing teenwerk.

Die doel van hierdie artikel is om 'n oorsig te gee van die persepsies van predikante, orreliste/ musiekleiers en gemeentelede met betrekking tot die aard en gebruik van die psalms binne die erediens van die Gereformeerde Kerke van Suid-Afrika, asook sinodebesluite wat hiermee verband hou.

KERNBEGRIPPE: Gereformeerde Kerke in Suid-Afrika, sinodebesluite, psalms, psalmberyming, psalmmelodie 


\section{INLEIDING}

Die Gereformeerde Kerke in Suid-Afrika (hierna GKSA genoem) is ' $n$ kerk wat in alles die Bybel en belydenisskrifte navolg. In die Gereformeerde erediens staan die Woordverkondiging sentraal en word daar hoofsaaklik psalms, Skrifberymings en Skrifgetroue liedere gesing. Die GKSA sien homself dus as 'n psalmsingende kerkverband (kyk onder andere Bingle, 2003). In 1911 skryf die Nederlandse teoloog, Abraham Kuyper, egter dat ten spyte daarvan dat Kerkordeartikel 69 (hierna K.a. 69 genoem) bepaal dat al 150 psalms in die Gereformeerde erediens gesing behoort te word, dit nie die geval is nie (Kuyper, 1911:65). Byna 'n eeu later toon Jacoba van Rooy (2008) en Driekie Jankowitz (2009) se navorsing oor die gebruik van die psalm in onderskeidelik die GKSA en NederduitsGereformeerde Kerk (hierna NGK genoem) ook aan dat diepsalm nie optimaal gebruik word nie. Beide Van Rooy en Jankowitz skryf die probleme aan tekstuele en musiekwetenskaplike faktore toe.

Die vraag wat gevolglik ontstaan het is wat die aandeel van die sinode, as besluitnemer oor wat in die GKSA moet gebeur, aan hierdie toedrag van sake is. Hierdie vraag word versterk toe 'n vooraanstaande Gereformeerde teoloog, prof. Bouke Spoelstra, in 2004 die sinode van "koerslose leiding" beskuldig (Spoelstra, 2004:273; kyk ook GKSA, 1985:404), of toe 'n beswaarskrif in 2003 die sinode - wat daarna streef om in alles Skriftuurlik op te tree - van onskriftuurlike optrede beskuldig in die onskriftuurlike beperking wat K.a. 69 op die werking van die Heilige Gees ten opsigte van die gawes in die plaaslike kerk plaas (GKSA, 2003:516).

Die doel van hierdie artikel is om 'n oorsig te gee van lidmate se persepsies met betrekking tot sinodebesluite oor die aard en gebruik van die psalms binne die erediens van die GKSA. Ná die kort bespreking van die navorsingsmetode, volg 'n bondige historiese oorsig met betrekking tot die gebruik van die psalm in die GKSA. Dit word gevolg deur 'n oorsig van sinodebesluite met betrekking tot die psalm en 'n ondersoek na lidmate se persepsies van sinodebesluite en die aard van die psalm. Ten slotte word 'n samevatting van die ondersoek gegee.

\section{NAVORSINGSMETODE}

Die navorsing ${ }^{1}$ het gefokus op die invloed van sinodebesluite op die gebruik van die psalm as kerklied binne die Afrikaanssprekende erediens van die GKSA. 'n Gemengde navorsingsmetode is gebruik wat bestaan het uit 'n argiefondersoek, asook 'n empiriese ondersoek.

Die argiefondersoek is gedoen om vas te stel wat die GKSAsinode se amptelike standpunt met betrekking tot die psalm as kerklied is. Vir dié doel is al die handelinge van die Nasionale of Algemene Sinode van die GKSA vanaf 1862 tot en met 2012 bestudeer.

'n Empiriese ondersoek onder Afrikaanssprekende gemeentes van die GKSA is gedoen met die doel om die mening van gemeentelede aangaande die psalm, die gebruik daarvan in die erediens en, in die besonder, hul persepsies oor sinodebesluite rakende die psalm te bepaal.

\section{PSALMSANG IN DIE GKSA}

Die gebruik van die GKSA om die 150 berymde psalms in die erediens te sing, kan na Calvyn teruggevoer word. Calvyn was bang dat die vrye lied, wat buite die Skrif staan, die objektiwiteit van die boodskap sou verduister en volstaan gevolglik met die psalms en enkele Nuwe-Testamentiese beryminge, waaronder die Apostoliese geloofsbelydenis (Barnard, 1985:336; Smelik, 1995:132).

Jan van Riebeeck se koms na Suid-Afrika in 1652 verplaas die Nederlandse kerklike patroon en die gebruik van die Datheenpsalmberyming na aanleiding van. besluite tydens die sinode vanDordrechtin1574 (Wepener, 2007:733), net so na die Kaap oor (Barnard, 1985:377). Die Datheen-beryming is in 1775 met die nuwe Stateberyming vervang (Cillié, 1983:8; Jankowitz, 2009:43, 48).

Die koms van die eerste Afrikaanse Bybelvertaling in 1933 het tot gevolg gehad dat 'n Afrikaanse psalmberyming nie langer uitgestel kon word nie. Ds. J.D. du Toit (Totius) (1877-1953) het opdrag ontvang om al die psalms in Afrikaans te berym en in 1936 is die 150 Afrikaanse psalms deur die GKSA in ontvangs geneem. In 1937 word die eerste Afrikaanse psalmboek met groot entoesiasme in die GKSA, en in 1944 met "louheid" ook in die NGK en Nederduitsch Hervormde Kerk (hierna NHK genoem) in gebruik geneem (Van Huyssteen, 2003:XVII; Van Wyk, 1983:65, 69). Hoewel daar kort ná die verskyning van hierdie beryming reeds kritiek ontvang word (kyk GKSA, 1939:46, 47), blyk dit egter vir 'n groot gedeelte van die GKSAgeskiedenis taamlik suksesvol te wees.

Ontevredenheid oor argaïese psalmtekste en moeilik singbare melodieë lei tot 'n versoek deur die NGK in 1957 dat daar aan die psalmtekste en -melodieë aandag gegee moet word. 'n Gesamentlike hersieningsproses deur die drie susterskerke (GKSA, NGK, NHK) begin in 1966 en lei tot 'n nuwe psalmboek wat in 1977 in die GKSA en in 1978 in die NGK en NHK in gebruik geneem word (Serfontein, 1983:134, 135). Steeds was die NGK nie tevrede nie en besluit die kerk se Algemene Sinode in 1978 dat 'n nuwe psalmberyming gemaak moet word. Ná ' $n$ lang konsultasieproses wys die NGK prof. T.T. Cloete van Potchefstroom in 1990 as teksdigter aan (Barnard, 2003:xxiv).

In 2001 word die Liedboek van die Kerk in die NGK en NHK in gebruik geneem waarin die nuwe psalmomdigting van T.T. Cloete, asook enkele omdigtings deur ander persone, opgeneem is. Ten spyte van kritiek teen hierdie omdigting (kyk GKSA, 2003:646, e.v.), word die 2001-omdigting saam met die 1936-beryming in Psalmboek 2003 gepubliseer en in 2003 in die GKSA in gebruik geneem (Bingle, 2003:vii). 


\section{SINODEBESLUITE RAKENDE DIE PSALMS}

Uit die argiefondersoek na sinodebesluite tussen 1862 en 2012 blyk dit dat die Skrif en belydenisskrifte van die GKSA die bepalende kriteria by sinodebesluite vorm. K.a. $69^{2}$ (kyk GKSA, 2012:385) bepaal slegs dat die 150 psalms gesing moet word, maar dit verskaf geen riglyne oor hoe die psalms gesing behoort te word nie. Die Skrif gee ook nie duidelike voorskrifte oor hoe die psalms gesing behoort te word nie (Basson, 2016:196).

Aanvanklike sinodebesluite (kyk onder andere GKSA, 1862, 1876, 1910 en 1913) handhaaf die Nederlandse bepalings en gebruike waarop daar tydens die Sinode van Dordrecht van 1618/19 besluit is, asook die besluit om die Nederlandse psalmberyming van 1773 te gebruik.

Dit is egter vroeg reeds duidelik dat daar probleme met die kerksang - met die psalms as belangrikste deel van die kerkliedkorpus - ondervind is. Die ontevredenheid met die psalms en 'n behoefte aan ander liedere lei gevolglik tot toenemende besprekingspunte oor die byvoeging van Skrifberymings en later ook ander Skrifgetroue liedere (kyk onder andere GKSA, 1869:41-44; 1873:48; 1907:31), asook die gebruik van die psalm as teenwig vir die aanslag van die vrye kerklied (Basson, 2016:196).

Vir 'n groot deel van die GKSA-geskiedenis fokus sinodes nie werklik op die musikologiese aspekte van die psalm nie. Telkens word die problematiese of onbevredigende kerksang bespreek sonder om konkrete bewys te lewer op grond waarvan die kerksang nie aan die sogenaamde verwagting voldoen nie. Dit is begryplik dat die psalmteks telkens die meeste aandag geniet, aangesien dit die gemeenskaplike faktor onder partye (waaronder kenners en niekenners, musici en niemusici, geleerdes en niegeleerdes) is. Wanneer die musikale komponent van psalms beoordeel word, word daar dikwels eerder 'n waardeoordeel uitgespreek (kyk onder andere GKSA, 1955:66, waar daar na die sogenaamde kenmerke van 'n geslaagde psalmmelodie verwys word) in plaas daarvan om musikologies verantwoordbaar die tekortkominge van spesifieke elemente te omskryf (Basson, 2016:196, 197).

Die sinode doen ook nie genoegsaam ondersoek onder alle lidmate en dooplidmate om 'n musikale profiel van die kerk te vorm wat as ' $n$ bykomende, kwalifiserende maatstaf by die keuse van liedtipes en geskikte melodieë toegepas sou kon word nie, ondanks talle vraelyste en ondersoeke (kyk onder andere GKSA, 1961, 1970, 1985) (Basson, 2016:198).

'n Verandering in denke en sienings aangaande die kerklied kan egter in die tweede helfte van die 20ste eeu in sinodebesluite (kyk onder andere GKSA, 1994 en 2012) waargeneem word. Vereistes waaraan die kerklied behoort te voldoen, word musikologies beter omskryf, maar steeds maak dit nie voorsiening vir die

$2 \quad$ K.a. 69 se bepaling dat Skrifberymings en ander Skrifgetroue liedere naas die psalms gesing moet word, is nie vir die doel van hierdie artikel ter sprake nie. toepassing van riglyne wat beter resultate tot gevolg sal hê nie (Basson 2016:197).

\section{LIDMATE SE PERSEPSIE VAN SINODEBESLUITE EN PSALMGEBRUIK}

In Oktober 2012 is 'n vraelys met behulp van die GKSA se Administratiewe Buro in Potchefstroom onder 274 Afrikaanssprekende gemeentes van die GKSA versprei. Inligting wat ingewin is, is deur die Statistiekdiens van die Noordwes-Universiteit (Potchefstroom) verwerk, terwyl die navorser vir die verwerking van antwoorde op oop vrae en algemene kommentaar verantwoordelik was.

Die vraelys het uit twee afdelings bestaan: Die eerste ses vrae het oor persoonlike besonderhede gehandel. Die tweede afdeling (vrae 7 tot 41) het oor die psalmgebruik gehandel. Altesaam 28 vrae het keuseopsies as moontlikhede gehad en 13 vrae was oop vrae. Vrae 31 tot 40 het spesifiek oor lidmate se kennis en persepsie van sinodebesluite en psalmgebruik gehandel. Altesaam 87 vraelyste, waarvan $37,2 \%$ deur predikante, $23,3 \%$ deur orreliste/musiekleiers en $39,5 \%$ deur gemeentelede beantwoord is, is terugontvang.

\subsection{Vergelyking tussen 1936-beryming en 2001-omdigting}

In 'n vergelyking tussen die psalmtekste van die 1936-beryming en 2001-omdigting, word die volgende duidelik:

Figuur 1: Beoordeling van psalmtekste

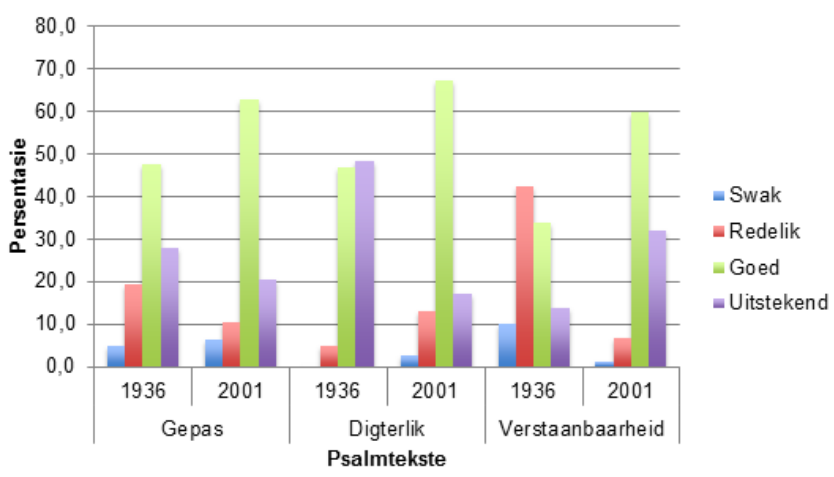

In totaal vind $83,3 \%$ van respondente die 2001-omdigting gepas vir kerklike gebruik, terwyl slegs 75,6\% die 1936-beryming vir kerklike gebruik gepas vind. 95,2\% van respondente glo dat die digterlike gehalte van die 1936-beryming goed tot uitstekend is, terwyl slegs $84,2 \%$ van respondente dieselfde voel oor die 2001-omdigting. Die syfer van respondente wat positief oor die verstaanbaarheid van die 1936 -beryming is, is $47,5 \%$, terwyl die meerderheid, naamlik 92,0\% van respondente, positief oor die 2001-omdigting se verstaanbaarheid is (Basson, 2016:134).

By die beoordeling van die singbaarheid van die psalms, het respondente soos volg gereageer: 
Figuur 2: Singbaarheid van psalms

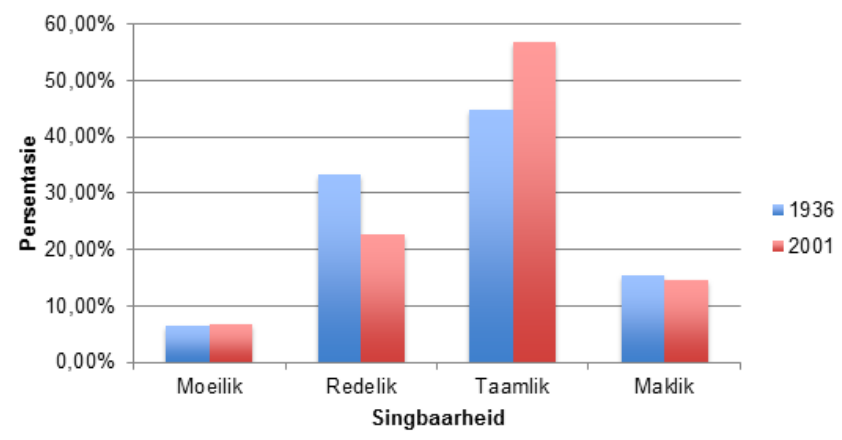

In totaal vind 60,3\% van die respondente die 1936-beryming taamlik tot maklik singbaar, terwyl 70,7\% van die respondente die 2001-omdigting taamlik tot maklik singbaar vind (Basson, 2016:135).

Wanneer redes vergelyk word waarom sommige psalms selde of nooit gesing word nie, word die volgende waargeneem:

Figuur 3: Redes waarom psalms selde of nooit gesing word

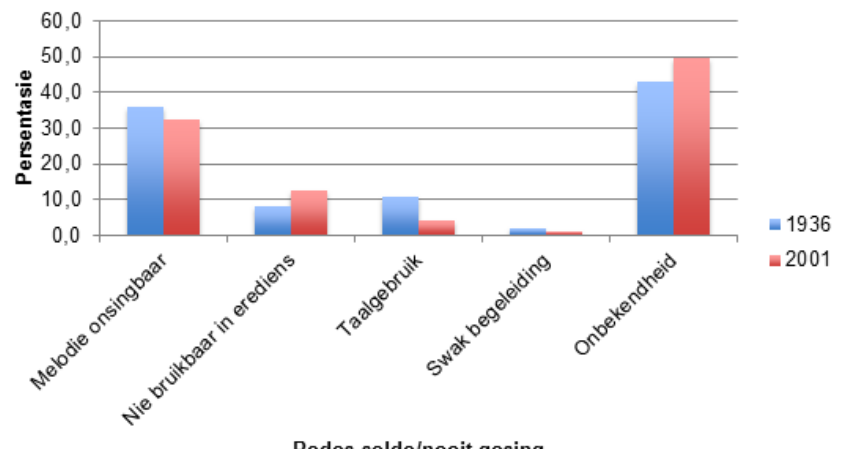

Redes selde/nooit gesing

Uit hierdie resultate blyk dit dat vir beide die 1936-beryming en 2001-omdigting die onbekendheid en vermeende onsingbaarheid van die psalms die twee belangrikste redes is waarom die psalms nie gesing word nie (kyk ook Vos \& Müller, 1990:94) (Basson, 2016:140).

\subsection{Lidmate se persepsie van sinodebesluite}

Die meerderheid $(86,7 \%)$ van respondente het aangedui dat hulle op hoogte van sinodebesluite met betrekking tot die psalmgebruik in die erediens is (Basson, 2016:106). Op die vraag of sinodebesluite in voeling is met die musikale behoeftes van lidmate het respondente soos volg gereageer (Basson, 2016:109):

\section{Figuur 4: Sinodebesluite en musikale behoeftes}

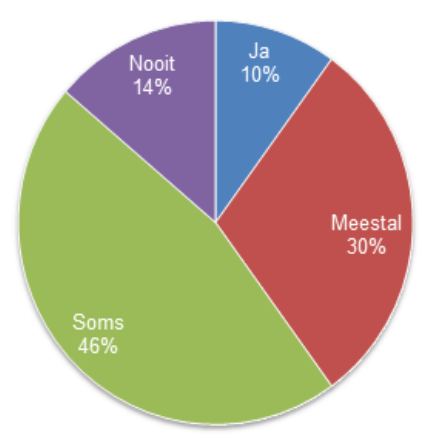

Uit bostaande figuur is dit waarneembaar dat die meerderheid van respondente van mening is dat die sinode soms of nooit in voeling is met lidmate se musikale behoeftes nie. Hoewel enkele respondente glo dat die deputate oor 'n grondige kennis beskik en in voeling is met lidmate se algemene musikale behoeftes, het respondente oorwegend negatief gereageer.

Volgens predikante word sinodebesluite op grond van 'n meerderheidstem geneem en dat die goedgekeurde liedere aan die behoeftes van baie gemeentelede voldoen. Die behoeftes verskil egter van persoon tot persoon. Bestaande besluite het voorts ' $n$ historiese konteks, terwyl lidmate se behoeftes voortdurend ontwikkel (Basson, 2016:109).

Predikante ervaar egter die sinode as onbuigbaar en aan te veel reëls gebonde, wat onder andere daartoe bydra dat die proses waarvolgens liedere gekeur word baie stadig verloop. Volgens respondente word daar te veel gefokus op wat mag of nie mag nie. Die feit dat die reëls net vir Afrikaanse psalms geld en nie vir Engelse psalms of psalms in Afrikatale nie, bevraagteken die geldigheid van beginsels waarvolgens psalms getoets word (Basson, 2016:109, 110). Nog 'n respondent glo dat besluite geneem word op grond van persepsies van 'n bepaalde demografiese snit en gevolglik sonder 'n akkurate profiel van alle lidmate in die GKSA, bv. demografie, taal, ouderdom, kulturele en subkulturele benaderings tot sang en musiek. Predikante glo ook dat besluite onrealistiese beperkings op lidmate se verskillende behoeftes en emosionele meelewing plaas (Basson, 2016:110).

Volgens respondent $215^{3}$ verstaan die sinode "nie werklik hoe belangrik dit vir lidmate is om bloot lekker singbare melodieë en woorde wat verstaanbaar is en uit die hart gesing kan word te hê nie". Hiermee saam is respondent 166 van mening dat jonger lidmate se veranderde musiekaanvoeling nie genoeg in ag geneem word by besluite nie (Basson, 2016:111).

Orreliste het positief en negatief op die sinodebesluite gereageer. Positiewe antwoorde dui daarop dat die sinode in voeling is, terwyl negatiewe antwoorde daarvan verskil. Orreliste wat kritiek uitspreek, het dit veral teen die gebruik van te veel melodieë uit die 1936-beryming en 2001-omdigting wat nie geskik is nie. Respondent 190 glo dat die sinode te veel 
aan uitgediende, ou praktyke vasklou wat die kerksang verarm. Volgens orreliste behoort lidmate aan 'n verskeidenheid van style blootgestel te word en dat dit ook belangrik is dat die sinode moet bepaal watter ander liedere deur gemeentes gesing en deur lidmate positief ervaar word (Basson, 2016:111).

Die Gereformeerde kerkliedere is volgens respondente geskik om in die erediens met orrelbegeleiding gesing te word, maar dit word problematies om die liedere buite die erediens, bv. skoolbyeenkomste en kampe onbegeleid te sing (Basson, 2016:112).

Heelwat respondente glo dat daar nie eenstemmigheid binne die sinode oor die kerklied is nie, dat daar te min nuwe liedere goedgekeur word en dat die sinode traag is met die goedkeuring van nuwe liedere. Respondent 273 beskryf die sinode as "gewoonlik 'n dekade te laat met "vernuwing"" (Basson, 2016:112).

Respondent 90 reageer soos volg (Basson, 2016:112):

Ek dink dat baie predikante/lidmate weet dat ons psalms argaïes, en somtyds tydgebonde vir die erediens onvanpas is. Maar ons mag dit nie sê nie! Tradisie en GKSA gebonde is ons met goue kettings gebind! Feitlik die enigste psalmsingers in die wêreld.

Respondent 45c glo dat die sinode nie tred hou met veranderinge nie (Basson, 2016:112):

Besluite gemaak 60 jaar gelede en word die jonger lidmate (18-40) totaal uitgesluit en predikante dwing hulle siening af op die lidmate. Kerkrade ook te oud (ouderdomsgewys).

Die opset binne die GKSA met betrekking tot die psalm en kerksang word as baie eng beskryf. Die klem word op verkeerde dinge gelê en nie op God wat aanbid moet word nie. Respondent 17 glo dat die sinode nie alleen kan besluit wat gepas is nie (Basson, 2016:112).

Gemeentelede is negatief oor die sogenaamde vreemde melodieë, asook melodieë wat steeds moeilik en volgens hulle onsingbaar is. Heelwat respondente spreek 'n behoefte aan 'n ander tipe musiek uit. Dit is veral opvallend dat hierdie behoefte uitgespreek word deur heelwat gemeentelede ouer as 55 jaar. Respondent 221 sluit hierby aan deur te sê dat jong en nuwe lidmate nie dieselfde sentimente as gevestigde lidmate het nie en gevolglik by 'n ander tipe musiek aanklank vind (Basson, 2016:112, 113). Respondent 12 reageer soos volg (Basson, 2016:113):

Daar is baie mooi [G]eneefse wysies, maar vir die gemiddelde kerkganger is die musiek te swaar op die oor. Ongelukkig is dit so, vir die meeste kerkgangers wil hulle net 'n psalm/Skrifberyming hê wat "lekker" sing.

\subsection{Kerkordeartikel 69}

Op die vraag of respondente saamstem met die bepaling van K.a. 69 dat al 150 psalms gesing behoort te word, het 58,5\% van respondente positief en $41,5 \%$ negatief gereageer (Basson, 2016:114).

Predikante wat positief gereageer het, doen dit op grond daarvan dat dit so deur die Heilige Gees in die Skrif bepaal is en dat die hele psalmbundel as lied aan die kerk gegee is. Respondent 175 is egter van mening dat die geskiedenis van die Kerkordeartikel aantoon dat dit ' $\mathrm{n}$ "verpligtende moet" is, terwyl respondent 248 dit as die "veiligste weg" beskryf (Basson, 2016:115).

Die singbaarheid kom weer eens ter sprake in predikante se reaksie op hierdie vraag. Die sogenaamde onsingbaarheid van heelwat psalms veroorsaak dat al 150 psalms nie gesing kan word nie. Respondent 28 reageer soos volg: “...veral met die klem op AL 150 met singbare wysies. Stel iemand aan wat maklike wysies gee aan elke onsingbare psalm. Tot ons sê nou kan ons hom sing" (Basson, 2016:116).

Predikante wat van hierdie artikel verskil, voer onder andere aan dat nie alle psalms en psalmverse vir erediensgebruik geskik is nie, dat sommige psalms vloekpsalms is en daarom nie gesing kan word nie, asook dat die Skrif nie bepaal dat net 150 psalms gesing moet word nie (Basson, 2016:116).

Volgens orreliste/musiekleiers is die gebruik van psalms onderhewig aan die tema van die preke of die tipe erediens. Nie alle tekste is egter altyd van toepassing nie. Respondent $15 \mathrm{skryf}$ dat elke psalm geskik is vir sy tyd, maar dat die tyd vir party psalms baie selde geskik is. Volgens respondent $13 \mathrm{~b}$ behoort nuwe omdigtings ' $n$ Nuwe-Testamentiese lig op die psalmtekste te laat val (Basson, 2016:117).

Benewens die tekste kom die singbaarheid ook weer ter sprake. Respondent 15 skryf soos volg:

Dit neem nie weg dat daar ook 'n klomp melodieë is waaroor 'n mens wonder hoekom dit hoegenaamd in die berymde psalmboeke beland het. Soveel moeite is gedoen om die melodieë te keur, te toonset en te druk, terwyl mens al vooraf kon geweet het dat die musiek nie geskik is vir vandag se smake nie (Basson, 2016:117).

Gemeentelede se reaksie toon ooreenskomste met predikante en orreliste/musiekleiers se reaksie op hierdie vraag. Gemeentelede glo ook dat problematiese tekste en melodieë talle psalms ongeskik vir erediensgebruik maak. Volgens respondent 90 is daar soms net een of twee verse van 'n betrokke psalm vir erediensgebruik geskik. Hierdie respondent verwys ook na die sogenaamde vloekpsalms, byvoorbeeld pss. $54,57,58,59$ en 60 , wat nie geskik is vir erediensgebruik nie (Basson, 2016:118).

\subsection{Beskikbaarheid van psalms in liedvorm}


Op die vraag of dit nodig is dat al 150 psalms in die psalmboek in liedvorm moet wees (aangesien 'n groot persentasie van psalms nie gesing word nie), het respondente se reaksie aansienlik verskil van hulle reaksie op die vraag met betrekking tot K.a. 69. Altesaam $77 \%$ van respondente glo dat al 150 psalms in liedvorm beskikbaar behoort te wees, terwyl $23 \%$ van respondente nie so voel nie (Basson, 2016:119). Die vraag wat ontstaan is waarom $77 \%$ van respondente van mening is dat al 150 psalms in liedvorm beskikbaar moet wees, terwyl slegs $58,5 \%$ van respondente van mening is dat al 150 psalms gesing behoort te word.

Die reaksie van predikante wat positief gereageer het, stem grotendeels ooreen met hulle reaksie op die vraag met betrekking tot K.a. 69. 'n Duidelike probleem met onsingbare melodieë wat hulle verhoed om spesifieke psalms in die erediens te laat sing, het weer eens sterk na vore getree. Respondent 273 skryf soos volg:

Baie min indien enige van die gemeentes in die land gebruik ooit al die psalms in 'n jaar. Almal verkies dit wat toepaslik is vir die erediens. Indien die psalms egter almal singbaar is, sal die prentjie verander (Basson, 2016:120).

Respondent 236 glo dat die onsingbaarheid van psalms 'n beperking plaas op wat gebruik kan word. Respondent 238 sluit hierby aan:

Omdat dit in eenheid is en in eenheid gebruik moet word. Ek het al baie van die moeilike psalms wou sing, maar weens die onsingbare melodie kon ek nie (Basson, 2016:120).

Dit was opvallend dat predikante ' $n$ behoefte aan ander liedtipes uitgespreek het. Twee respondente het 'n behoefte uitgespreek aan die gebruik van chanting of praatsang (vergelyk die gebruik van chanting in onder andere die Anglikaanse en Lutherse kerk). Volgens respondent 166 kry die woorde met hierdie tipe sang meer aandag. Respondent 25 het weer behoefte aan meer eietydse (kontemporêre) psalms en verwys onder andere na die gospelsanger, Louis Britzz ${ }^{4}$, se nuwe berymings (Basson, 2016:120, 121).

Orreliste en musiekleiers se reaksie het, net soos dié van predikante, grotendeels ooreengestem met hulle reaksie op die vraag oor K.a. 69. Orreliste/musiekleiers glo egter dat die onbruikbaarheid van sommige psalms in die erediens dit nie noodsaaklik maak dat al 150 psalms in liedvorm beskikbaar hoef te wees nie en eerder vir individuele gebruik geskik sou wees (Basson, 2016:121).

Gemeentelede glo dat die psalms in liedvorm beskikbaar behoort te wees, sou dit nodig wees om 'n spesifieke psalm te laat sing. Gemeentelede glo wel dat die psalms in ander vorms beskikbaar sou kon wees, aangesien dit byvoorbeeld goed is om soms net die psalms te lees. Die moeilik singbaarheid

$4 \quad$ Louis Britzz het reeds twee CD's met psalms opgeneem, nl. Psalms (2011) en Psalms 2 (2012) (Britzz, 2016). van psalms behoort egter aandag te kry en ook gemeentelede toon behoefte aan meer eietydse, kontemporêre melodieë (Basson, 2016:121, 122).

\subsection{Algemene kommentaar met betrekking tot die psalms}

Op die vraag watter veranderinge ter verbetering aan die twee psalmberymings en die gebruik daarvan binne die erediens aangebring sou kon word, is uiteenlopende reaksies ontvang. Antwoorde van predikante by hierdie vraag dui op 'n dringendheid en frustrasie wat ervaar word met' $n$ gebrek aan maklik singbare melodieë. Daar is ook ' $n$ duidelike behoefte aan meer eietydse of kontemporêre psalmmelodieë (Basson, 2016:123).

Orreliste/musiekleiers en gemeentelede het waardevolle kommentaar op hierdie vraag gegee. Net soos die geval met predikante het orreliste/musiekleiers en gemeentelede ook behoefte aan makliker singbare melodieë wat wegbeweeg van die huidige Geneefse psalmstyl. Respondent 92 sluit hierby aan deur te sê dat die toonsettings by die "musikale oor van die 21ste eeu" moet aanpas. Voorts behoort liedere van verskillende digters/komponiste oorweeg te word. 'n Groter verskeidenheid harmonisasies behoort ook ingesluit te word. Gemeentelede het, benewens die behoefte aan beter psalmmelodieë, ook voorgestel dat daar weer aan psalmtekste aandag gegee word (Basson, 2016:125, 126).

Op die vraag of daar enige verdere kommentaar op die psalms en die gebruik daarvan binne die GKSA is, het predikante weer eens uiteenlopend gereageer. Die kwessie van die singbaarheid van psalms het ook weer ter sprake gekom. Respondent 28 het uitgesproke gereageer:

Al die vuil psalms [verwysend na die 1936-beryming] wat sekerlik aan $\mathrm{u}$ bekend is. Baie psalms word nie gesing nie oor hulle wysie in beide die 2001 en 1936 berymings. Nog nooit durf iemand nuwe melodie skryf en vir elke psalm 'n singbare melodie te gee nie. Dom!!! (Basson, 2016:129).

Respondent 246 waarsku egter dat die psalms nie tot die "een en al van kerklike musiek" verhef behoort te word nie. Respondent 238 glo dat lidmate ingelig behoort te word waarom psalms gesing word, sodat dit 'n daadwerklike geloofsdaad word en nie maar net ' $n$ tradisie sal bly nie. Respondent 114 sluit hierby aan:

Die eise van die Skrif vir die erediens as Godsontmoeting is baie dieper en meer veeleisend as' $n$ sinodaal goedgekeurde, eenvormige psalmboek. Elke gemeente se ouderlinge moet verantwoordelikheid aanvaar vir wat gesing word. Hulle moet hulle aan Gereformeerde beginsels en nie Gereformeerde vorme nie, onderwerp; d.w.s. nie aan bepaalde berymings, bepaalde melodieë, ens. nie. Dit mag 'n gevaarliker pad wees, maar dis m.i. die Skriftuurlike pad (Basson, 2016:128).

Enkele predikante glo ook dat die feit dat talle psalms nie in die 
eerste persoon berym is nie, dit moeilik maak vir lidmate om psalms uit die hart te sing (Basson, 2016:129).

Volgens orreliste/musiekleiers beskik die psalms oor 'n groot potensiaal, maar gaan dit tans onder historiese bagasie gebuk. Die feit dat heelwat psalms nie gesing word nie, word egter aan predikante, wat net liedere kies wat aan hulle bekend is, toegeskryf. Doeltreffende begeleiding en die inoefening van moeilike psalms behoort die gebruik daarvan te bevorder (Basson, 2016:129).

Gemeentelede het ook by hierdie vraag op die behoefte aan singbare melodieë verwys. Enkele respondente het ook daarop gewys dat lidmate nie geken word in besluitneming nie, of dat voorstelle ter verbetering van die sang nie in ag geneem word nie.

Enkele respondente het ook melding gemaak van die feit dat eredienste mense verveel en dat die psalms geneig is om eentonig voor te kom, veral wanneer dit met die melodieë van liedere uit die Liedboek van die Kerk vergelyk word. Respondent 90 skryf soos volg (Basson, 2016:131):

Solank ons onbuigsaam, dwingend, verkramp die outydse psalms alleenlik sing, sal ons gemeentes krimp en uitsterf. Ons eredienste bly strak en vreugdeloos. Die meeste psalms sê nie, soos die liedere in die Liedboek wat die lidmaat aan God wil sê nie - wat ons sing is/moet gesonge gebede wees!!

\section{SAMEVATTING}

Die volgende gevolgtrekkings kan uit hierdie ondersoek gemaak word:

- Die singbaarheid van die psalms is steeds 'n belangrike kwessie.

- Die psalms in die psalmboek is nie geskik vir optimale gebruik deur die 21ste-eeuse lidmaat nie.

- $\quad$ Sinodebesluite rakende die psalms hou nie rekening met die musiek- en ander behoeftes van lidmate nie.

- Sinodebesluite dra nie by tot kerkmusiekvernuwing nie.

Dit is duidelik dat daar onder predikante, orreliste, musiekleiers en gemeentelede nie eenstemmigheid oor die twee amptelike psalmberymings in gebruik binne die GKSA is nie. Die gemeente, as eindgebruiker, dien as 'n duidelike aanduider van die sukses al dan nie van sinodebesluite. Indien gemeentes nie die psalms sing wat deur die sinode goedgekeur word nie, is dit ' $n$ aanduiding daarvan dat die goedgekeurde liedere nie aan gemeentes se behoeftes voldoen nie. Die sinode behoort gevolglik daarop ag te slaan en kennis te neem van lidmate se persepsies in hierdie verband.
Die outeurs verklaar dat hulle geen finansiële of persoonlike verbintenis het met enige party wat hulle nadelig of voordelig kon beïnvloed in die skryf van hierdie artikel nie.

\section{ERKENNING}




\section{LITERATUURVERWYSINGS}

BARNARD, A.C. 1985. Die erediens. 2de druk. Pretoria: NG Kerk Boekhandel.

BARNARD, A.C. 2003. Voorwoord by die Psalms. (In Psalmboek: Die berymde en omgedigte psalms en ander Skrifberymings in gebruik by die Gereformeerde Kerke in Suid-Afrika. Kaapstad: NG Kerk-Uitgewers.)

BASSON, W.D. 2016. Die invloed van sinodebesluite op die psalm as kerklied in die Gereformeerde Kerke in Suid-Afrika. Potchefstroom: Noordwes-Universiteit. (PhD-proefskrif.)

BINGLE, J.P. 2003. Voorwoord van die Eindredakteur. (In Bingle, J.P., Van Rooy, H.F. \& Van Rooy, J., reds., Psalmboek: Die berymde en omgedigte psalms en ander Skrifberymings in gebruik by die Gereformeerde Kerke in Suid-Afrika. Kaapstad: NG Kerk-Uitgewers. p. VII-XIII.)

BRITZZ, L. 2016. What's new? http://www.louisbrittz.co.za/new.html. Datum van gebruik: 15 Julie 2016.

CILLlé, G.G. 1983. Die Kerklied in Suid-Afrika, 1652-1800. (In Du Toit, J.H.H., red. 'n Geskiedenis van die Afrikaanse Protestantse kerklied. Transvaal: NG Kerkboekhandel. p. 1-10).

GKSA. 1862. Handelingen van de Eerste Algemeene Sijnodale Vergadering der Gereformeerde Kerk, van de Zuid-Afrikaansche Republiek, den Oranje Vrijstaat en die Kaap-Kolonie in Zuid-Afrika gehouden van den 20-24 Maart 1862, te Reddersburg (Oranje Vrijstaat). Kaapstad: Saul Solomon.

GKSA. 1869. Handelingen van de Vierde Algemeene Synodale Kerkvergadering samengesteld uit al de Gereformeerde Gemeenten van Zuid-Afrika. Vergaderd te Potchefstroom (Zuid-Afrikaansche Republiek), den 17den Mei, 1869 en volgende dagen. Kaapstad: Saul Solomon.

GKSA. 1873. Handelingen van de Vijfde Algemeene Synodale Kerkvergadering, samengesteld uit al de Gereformeerde Gemeenten van Zuid-Afrika, vergaderd te Burgersdorp (Kaapkolonie), van den 7 den tot den 17den April 1873. Kaapstad: Saul Solomon.

GKSA. 1876. Handelingen van de Zesde Algemeene Synodale Kerkvergadering, samengesteld uit al de Gereformeerde Gemeenten van Zuid-Afrika, vergaderd te Reddersburg (Oranje-Vrijstaat), van den 8sten tot den 24sten Mei 1876. Kaapstad: Saul Solomon.

GKSA. 1907. Handelingen van de Vijftiende Algem. Synodale Kerkvergadering samengesteld uit al de Gereformeerde Gemeenten van Zuid-Afrika, vergaderd te Pretoria, Transvaal, van den 4den Maart tot den 14den Maart 1907. Pretoria: N.D. van der Reyden.

GKSA. 1910. Handelingen van de Zestiende Algemene Synodale Vergadering van de Gereformeerde Gemeenten van Zuid-Afrika, vergaderd te Reddersburg van de 7de tot de 17 de Maart 1910. Pretoria: N.D. van der Reyden.

GKSA. 1913. Handelingen van de Zeventiende Algemene Synodale Vergadering van de Gereformeerde Gemeenten van Zuid-Afrika, vergaderd te Steynsburg op de 6de Maart en daaropvolgende dagen. Pretoria: N.D. van der Reyden.

GKSA. 1939. Handelinge van die 26ste Sinodale Vergadering van die Gereformeerde Gemeentes in Suid-Afrika in sitting byeen te Bloemfontein, O.V.S., op Woensdag 23 Maart, 1939 en volgende dae. s.l.

GKSA. 1955. Handelinge van die 32ste Sinodale Vergadering van die Gereformeerde Kerk in Suid-Afrika in sitting byeen te Potchefstroom op Woensdag, 26 Januarie 1955 en volgende dae. Pretoria: V\&R.

GKSA. 1961. Handelinge van die Vier-en-Dertigste Sinodale Vergadering van die Gereformeerde Kerk in Suid-Afrika in sitting byeen te Potchefstroom op Woensdag 25 Januarie 1961 en volgende dae. s.l.

GKSA. 1970. Handelinge van die Sewe-en-Dertigste Sinodale Vergadering van die Gereformeerde Kerk in Suid-Afrika in sitting byeen te Potchefstroom op 21 Januarie 1970 en volgende dae. s.l.
GKSA. 1985. Handelinge van die Twee-en-Veertigste Nasionale Sinode in Potchefstroom op 8 Januarie 1985 en volgende dae. Potchefstroom: Potchefstroom Herald.

GKSA. 1994. Handelinge van die Vyf-en-Veertigste Nasionale Sinode te Potchefstroom op 3 Januarie 1994 en volgende dae. Potchefstroom: Potchefstroom Herald.

GKSA. 2003. Handelinge van die Agt-en-Veertigste Nasionale Sinode te Potchefstroom op 6 Januarie 2003 en volgende dae. Pretoria: V\&R.

GKSA. 2012. Handelinge van die Tweede Algemene Sinode te Potchefstroom op 4 Januarie 2012 en volgende dae. Pretoria: V\&R.

JANKOWITZ, H.J. 2009. Die praktyk van liturgiese psalmsang in die NG Kerk in Suid-Afrika en Namibië. Potchefstroom: Noordwes-Universiteit. (PhD-proefskrif.)

KUYPER, A. 1911. Onze Eeredienst. Kampen: J.H. Kok.

SERFONTEIN, W.J.B. 1983. Die ontstaan van die kerksangbundel van 1978. (In Du Toit, J.H.H., red. 'n Geskiedenis van die Afrikaanse Protestantse kerklied. Transvaal: NG Kerkboekhandel. p. 131-145).

SMELIK, J. 1995. Gezangbundels uit de periode 1566-1900 (In Ingelse, C., Van Laar, J.D., Sanderman, D. \& Smelik, J., reds. Nieuw handboek voor de kerkorganist. Zoetermeer: Uitgeverij Boeken-centrum. p. 132-146).

SPOELSTRA, B. 2004. Het die Reformasie die leer gered en aanbidding verloor? Acta Theologica, Supplementum 3:270-291.

VAN HUYSSTEEN, P.H. 2003. Voorwoord van die kommissie van reviseurs (In Bingle, J.P., Van Rooy, H.F. \& Van Rooy, J., reds., Psalmboek: Die berymde en omgedigte psalms en ander Skrifberymings in gebruik by die Gereformeerde Kerke in Suid-Afrika. Kaapstad: NG Kerk-Uitgewers. p. XV-XVII.)

VAN ROOY, J.H. 2008. Die Psalmboek 2003 as kommunikasiemiddel in die liturgie van die erediens in die Gereformeerde Kerke in Suid-Afrika: ' $n$ himnologiese studie. Potchefstroom: Noordwes-Universiteit. (PhD-proefskrif.)

VAN WYK, D.J.C. 1983. Die beryming van die Psalms in Afrikaans. (In Du Toit, J.H.H., red. 'n Geskiedenis van die Afrikaanse Protestantse kerklied. Transvaal: NG Kerkboekhandel. p. 64-75).

VOS, C.J.A. \& MüLLER, J.C. 1990. Die sing van psalms in die erediens: ‘n Kommunikatiewe handelingsteoretiese perspektief. Praktiese Teologie in Suid-Afrika, $6(1): 86-98$.

WEPENER, C. 2007. Participation and power. Opportunities for method and theory in liturgical research from a changing (Dutch Reformed) South African liturgical landscape. Nederduitse Gereformeerde Teologiese Tydskrif, 48 (3\&4):730-742. 